\title{
THE NEGRO MINE LABORER: CENTRAL APPALACHIAN COAL FIELD
}

By George T. Surface, Ph.D.,

Instructor in Geography, Sheffield Scientific School, Yale University,

New Haven, Conn.

The Field

The area under discussion is midway between the northern limit of the Pennsylvania coal field and the southern limit of the Alabama field. Both the geographical situation and the economic conditions make it proper to group the southern part of the Tennessee coal area with the Alabama field, and the northern part of the West Virginia area with the Pennsylvania field. This discussion, therefore, relates to that part of the West Virginia field situated south of and including the Kanawha River and New River valleys; that part of the Kentucky field contiguous to the Virginia and Tennessee fields; all of the Virginia field situated in the Appalachian System; and that part of the Tennessee field north of the Wartburg Basin, of which Morgan County is the center.

The most important developed centers in this large territory are situated in the following counties: Kanawha, Fayette, Raleigh, Mercer, McDowell and Mingo (West Virginia); Tazewell, Russell, Dickinson, Wise and Lee (Virginia); Bell, Knox and Whitley (Kentucky); Anderson, Campbell and Claiborne (Tennessee).

The investigation as herein discussed is based upon as accurate statistics and observations as could be obtained in representative centers throughout the territory outlined above. In so far as figures are discussed, the article will be limited to fifty operations which we believe to represent with fair accuracy the general conditions. From these we can arrive at some definite conclusions, both as to the present efficiency of the negro as a mining laborer in this field, the economic changes in progress, and those likely to be realized in the near future.

The chief purpose of the paper is to give information which will show the present status of the negro as a mining laborer, and $\left(33^{8}\right)$ 
his relative efficiency. It is impracticable to attempt to reduce his labor to terms of absolute efficiency, on account of the methods of bookkeeping generally in vogue, and the irregularity of the car supply which, in so far as it is inadequate, could not be justly used as an offset to the laborer's efficiency. If the supply of work were regularly continuous, and the car supply adequate, it would be easy to reduce each miner's work to an equation of personal efficiency. Only two companies in the field attempt to keep an absolute record of the men by reducing the time and output of each miner to a numerical standard.

\section{A. Chief Factors Controlling Efficiency}

I. Physical Ability.-Although efficiency does not conform very closely to physical ability, that constitutes one of the primary requisites for maximum efficiency in any labor requiring so much physical exertion as that of mining. The negro miners of this field compare in physical strength very favorably with all other classes. In the first place, the work seldom appeals to the individual of subnormal strength and endurance, and should such drift into the field, they soon recoil from the labor, or are supplanted by more productive laborers. It was quite obvious throughout the investigation that the majority of those in the class of maximum producers were the possessors of strong physique.

2. Standard of Living.- Since the physical strength depends in a large measure upon the character and regularity of the food supply, this factor should not be overlooked. As a class, the negro miners throughout the field maintain a high standard in the purchase of food supplies. In fact, from the standpoint of expenditure, their standard, as proportionate to wages, is higher than that of any other mining class. A reference to the table will show that almost every operator expressed the opinion that the negroes as a class spend not less than 90 per cent of their total earnings, and it would be equally accurate to affirm that 90 per cent of the total negro miners employed spend all of their earnings. They also maintain a standard commensurate with any other class in the quality and comfort of clothing. As to the percentage of the total wage which is consumed for food supplies, it is impossible to give more than an estimate. I inferred from an examination of numerous store accounts, that an average of 40 per cent of the total wage 
was consumed in the purchase of food stuffs, and that 25 per cent of the total wage was consumed in the purchase of clothing.

3. Regularity of Labor.-The first consideration under this topic is the regularity of employment. At the time this investigation was made (the summer of 1907 ) there was an alarming deficiency of laborers, because of the abnormal demand for the output. We believe, therefore, that the figures approach the normal efficiency of the laborer more closely than they would in a time of excessive competition. By normal efficiency, we mean that which is the expression of what may be expected without coercion. There was at this time an inadequate supply of cars, but this affected all laborers alike, so that it does not complicate the discussion which has for its purpose the relative efficiency of any laboring class.

Forty-one per cent of the operators interviewed reported their negro miners as working less than four days per week. Only 5 per cent reported the negroes as working more than four days per week. No operator reported his foreign classes as working less than four days per week, and 25 per cent of all operators employing foreign labor reported the foreign classes as working more than four days per week. This shows that the negro is more irregular as a laborer than the foreign labor employed, and in the majority of cases it was equally evident that he was more irregular than the American white labor employed. The fact that the negro is so irregular as not to justify the employer depending upon him for a maximum output, whatever the circumstances may be demanding that maximum output, is the most serious handicap to the negro as a mining class in all parts of the field where they are employed in conspicuous numbers.

4. Stability of Residence.-It would be expected that the class which is most irregular in the performance of its work would be the most unstable in a continuance of that labor, but this is not true, since as a class the negro miners are more stable in their residence than any of the foreign classes located in the field in question, excepting the miners from the British Isles. From the estimates of the fifty operators interviewed, it appears that an average of 50 per cent of all negroes employed change their residence within one year. The foreign classes (with the exceptions above noted) change so frequently as to make a conclusion a mere guess. This question is one of vital importance to the employer. Houses must be provided 
with reference to the number of laborers required. To have these houses occupied by migrating workmen makes it necessary that a much larger number of houses be constructed than would be required by a more permanent residential class.

5. Skill of Labor.-At every operation visited it was found that the maximum producing negro miners were on a par with the maximum producing miners of all other classes. This small class of maximum producers consisted almost entirely of men who had been in the field for many years, men who were strong in body, and in most cases were conservative and systematic in their habits. In pick mining, there is no question but that the negro has the potential power to hold his ground with any competitor. The same may be said of his ability as a coke puller, and we feel warranted in saying that as a coke puller he is the most efficient and most satisfactory of the different classes employed. One of the things which militate strongly against the negro in the field of mining competition is that he is not adapted to any kind of skilled work. At least, every operator gave as his opinion that for skilled work, either in the yard, in timbering, or in the manipulation of mining machinery, the American whites are so far his superior as to be generally employed. This fact is indexed in the statistics of the 1907 report of the Chief Inspector of Mines of West Virginia (see Table I A and B), in which we find that the table showing total percentage of negro laborers approximately corresponds inversely to the table giving the percentage of the total coal mined by machinery in the several counties.

TABLE I A.

West Virginia-Statistics from 1907 Report of Chief Inspector of Mines.

\begin{tabular}{|c|c|c|c|}
\hline County. & $\begin{array}{c}\text { Total } \\
\text { Laborers. }\end{array}$ & $\begin{array}{l}\text { Total } \\
\text { Negroes. }\end{array}$ & $\begin{array}{l}\text { Per cent } \\
\text { Negroes. }\end{array}$ \\
\hline Mercer & 2,586 & $\mathrm{r}, 022$ & 39.5 \\
\hline McDowell & I I , 897 & 4,300 & 36.2 \\
\hline Mingo & 2,603 & 123 & 5 \\
\hline Kanawha & 7,054 & 693 & 9.8 \\
\hline Fayette & I I, 693 & $2,78 I$ & 23.7 \\
\hline Raleigh & 1,729 & 304 & 17.6 \\
\hline
\end{tabular}


TABLE I B.

Production-Showing Machine Mined Coal in West Virginia By Countres, 1907.

(Tons of 2,240 pounds.)

\begin{tabular}{|c|c|c|c|c|}
\hline County & $\begin{array}{l}\text { Machine } \\
\text { mined. }\end{array}$ & $\begin{array}{l}\text { Pick } \\
\text { mined. }\end{array}$ & $\begin{array}{c}\text { Total } \\
\text { Production }\end{array}$ & $\begin{array}{l}\text { Percentage } \\
\text { of total, } \\
\text { machine } \\
\text { mined. }\end{array}$ \\
\hline Mercer & 97,044 & $\mathrm{I}, 9 \mathrm{I} 2,478$ & $2,009,522$ & $4+$ \\
\hline McDowell ..... & 457,909 & $7,665,790$ & $8,123,699$ & 5.6 \\
\hline Mingo ......... & $\mathrm{I}, \mathrm{I} 62,04 \mathrm{I}$ & 705,059 & $\mathrm{I}, 867,100$ & $62+$ \\
\hline Kanawha ....... & $3,272,386$ & $I, 353,715$ & $4,626, \mathrm{IOI}$ & 77 \\
\hline Fayette ....... & $1,870,842$ & $5,406,455$ & $7,277,297$ & $25+$ \\
\hline Raleigh & 50,049 & $1,054,627$ & $\mathrm{I}, \mathrm{I04}, 676$ & 4.8 \\
\hline
\end{tabular}

The average output of the negro miners as a class is somewhat below that of the different foreign classes and of the American whites, chiefly because of the shorter time worked. It seems that the amount by which he is below an average production, is to be accounted for chiefly by the factor of irregularity. No laborer can maintain as high a percentage of production by irregular as by regular work. He has not only the distraction of mind and body which comes from the time he is out, but consumes a certain amount of time in regaining his place and equipment, which would be ready for him, were he so regular as to be expected for all working hours.

6. The Care of Property.- Since the employer figures efficiency with reference not only to tons, but to the net cost of production, the care of property constitutes a basal factor of efficiency. Twentyfour of the fifty operators reported the negro as abusing property more than either the American whites or the foreigners. Of the remaining twenty-six, about half could make no discrimination between the several classes. A few of the operators reported the negro as exercising greater care in the use of property than the foreign classes employed. From the fact that 50 per cent of the operators considered the negro as most destructive to the property used, there is sufficient reason to conclude that this is one of the handicaps against the negro's gaining a higher place in the scale of competition.

7. The Spirit of Personal Interest.-In any aggregation of laborers, this is a very important factor, since it is the soundest impulse for the most satisfactory economic realizations. It is indeed difficult to analyze the personnel of negro miners in this particular, 
since they are influenced by so many conditions and motives. The negro is by nature ostentatious and if he be an industrious and productive miner, he finds much pleasure in lauding over his fellows the victories which he may have won in out-rivalling them in output. His personal interest is stirred by the ambition to exceed. Others become closely attached to the man under whose directions they work, and if my interpretation of the negro character be correct, I would say that herein lies the greatest possibility for creating among the negro miners a personal interest in the work assigned. There are a few who seem to love the work and the place, and take that personal interest which would be expected of them were they the owners of the mines.

8. Response to Direction.-The negro is easily controlled, except in times of confusion and clash. He willingly submits to supervision, but as a rule cannot be depended upon to exercise very important initiative. In working together negroes respond in unison to the reasonable demands made upon them, and are more easily controlled with reference to mechanical performance than either the American whites or the foreign classes.

9. Personal Habits.-The personal habits of the negroes as a mining class are unfortunately such as not to increase their efficiency, but on the other hand to diminish it materially. The negro's moral weakness is in reality more pronounced than his economic incapacity, and since the fostering of the former but accentuates the latter, the two react upon the home life with destructive results. The home life of the negro in most parts of the field investigated is so loose and indiscriminate that even the operators can give but little information as to the percentage of the legitimate negro homes. We do not have to look far for the explanation, since individual moral restraint must be largely the preventing barrier, there are few social or legal barriers. The population is not sufficiently stationary for social lines to become clearly marked and the negroes as a class are but indifferently discriminating in this regard, even in stationary communities. It is true that there is a small conservative class of negroes whose personal habits are above reproach. These usually live quietly by themselves and have but little uplifting influence upon those whose conduct they deprecate. The American whites of this territory have a natural antipathy for being mixed up with the colored population, and as a rule the 
TABLE II.-STATISTICAL COMPARISON TO SHOW THE RELATIVE EFFICIENCY OF

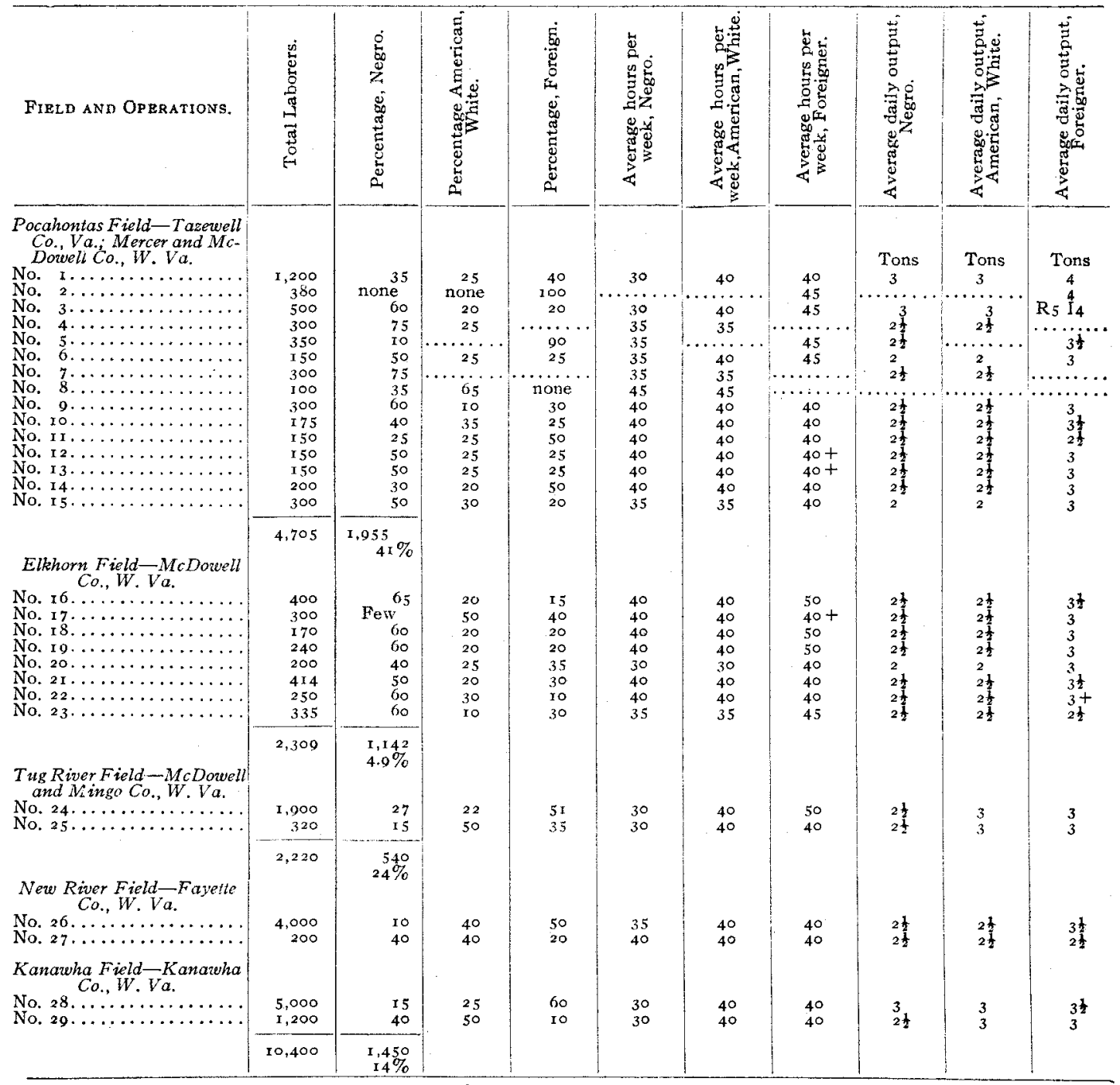

(a) Estimate of operators as to proportion of total wages consumed.

(b) 14 negro miners took up in store $\$ 414 ; 14$ American whites took up the same month $\$ 415 ;$ while 28 Hungarian miners took up $\$ 776$. 
THE NEGRO AS A MINING LABORER IN THE CENTRAL APPALACHIAN COAL FIELDS.

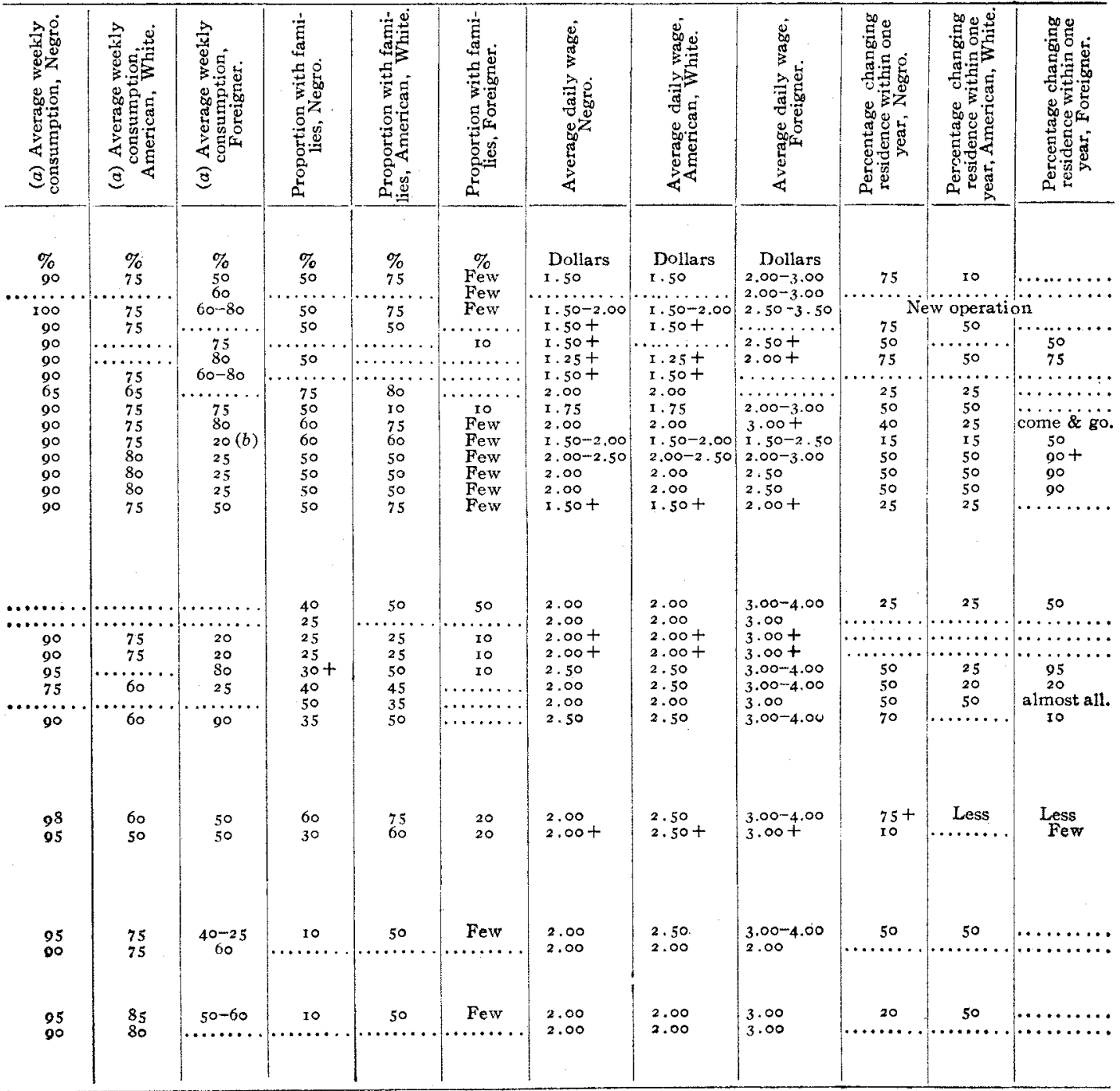


TABLE II.-Continued.

\begin{tabular}{|c|c|c|c|c|c|c|c|c|c|c|}
\hline Field and Operations. & 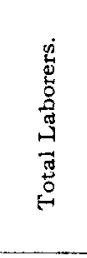 & 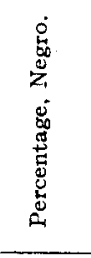 & 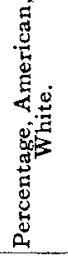 & 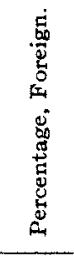 & 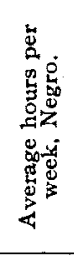 & 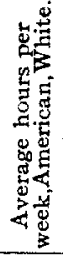 & 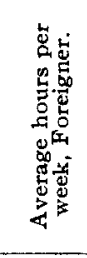 & 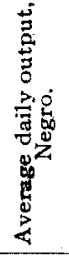 & 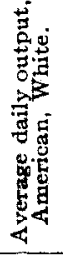 & 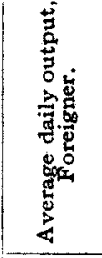 \\
\hline \multicolumn{11}{|l|}{$\begin{array}{l}\text { Big Stone Gap Field-Wise, } \\
\text { Russell and Dickinson Co., } \\
\text { Va. }\end{array}$} \\
\hline No. $30 \ldots \ldots \ldots$ & $\begin{array}{r}2,000 \\
700\end{array}$ & $\begin{array}{r}25 \\
35\end{array}$ & 25 & 50 & 35 & 35 & 40 & 31 & $3 \frac{2}{2}$ & 41 \\
\hline $\begin{array}{l}\text { No. } 31 \text {. } \\
\text { No. } 32 \text {. }\end{array}$ & $\begin{array}{l}700 \\
250\end{array}$ & $\begin{array}{l}35 \\
50\end{array}$ & $\begin{array}{l}30 \\
35\end{array}$ & $\begin{array}{l}35 \\
15\end{array}$ & $\begin{array}{l}35 \\
40\end{array}$ & $\begin{array}{l}35 \\
40\end{array}$ & $\begin{array}{l}4 \circ \\
4 \circ\end{array}$ & $\frac{3 \pi}{4 \frac{1}{2}}$ & $4 \frac{3}{4}$ & $4 t^{4-5}$ \\
\hline $\begin{array}{l}\text { No. } 33 \ldots \ldots \ldots \ldots \ldots \ldots \ldots \ldots \ldots \\
\text { No. } 34, \ldots \ldots \ldots \ldots \ldots \ldots\end{array}$ & $\begin{array}{r}1,400 \\
200\end{array}$ & 30 & 40 & 30 & 40 & 40 & 40 & 4 & 4 & 4 \\
\hline \multirow[t]{2}{*}{ No. $34, \ldots \ldots \ldots \ldots \ldots$} & 200 & 20 & 70 & 10 & 40 & 40 & 40 & 4 & 4 & 4 \\
\hline & $4,55^{\circ}$ & $\begin{array}{r}1,3.35 \\
30 \%\end{array}$ & & & & & & & & \\
\hline \multicolumn{11}{|l|}{$\begin{array}{c}\text { Eastern } K y . \text { Whitley, Bell } \\
\text { and Knox Cos. }\end{array}$} \\
\hline $\begin{array}{l}\text { No. } 35 \ldots \ldots \ldots \\
\text { No. } 36, \ldots \ldots \\
\text { No } 37\end{array}$ & $\begin{array}{r}300 \\
50\end{array}$ & $\begin{array}{l}\text { I5 } \\
\text { I0 }\end{array}$ & $\begin{array}{l}85 \\
90\end{array}$ & $\begin{array}{l}\text { none } \\
\text { none }\end{array}$ & $\begin{array}{l}40 \\
40\end{array}$ & $\begin{array}{l}40 \\
40\end{array}$ & $\ldots$ & 5 & 5 & ..... \\
\hline $\begin{array}{l}\text { No. } 37 \ldots \ldots \ldots \ldots \ldots \ldots \ldots \\
\text { No. } 38, \ldots \ldots \ldots \ldots\end{array}$ & $\begin{array}{l}50 \\
50\end{array}$ & none & roo & none & & ${ }_{50}^{40}$ & & 4 & $\begin{array}{l}4 \\
3\end{array}$ & 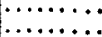 \\
\hline $\begin{array}{l}\text { No. } 38 \ldots \\
\text { No. } 39 . . .\end{array}$ & 100 & none & 100 & none & $\cdots$ & 50 & ….... & $\cdots$ & 5 & 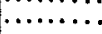 \\
\hline$\cdots \cdots$ & $\begin{array}{l}50 \\
75\end{array}$ & ${ }_{5}$ & $\begin{array}{c}100 \\
95\end{array}$ & $\begin{array}{l}\text { none } \\
\text { none }\end{array}$ & " & & $\because$ & . & & $\ldots \ldots$ \\
\hline No. $4 T$. & 300 & Few & & 50 & 20 & 30 & $40^{\circ}$ & $\ddot{2 i}$ & $\dddot{2 i}$ & 4 \\
\hline$A$ & 200 & none & $\begin{array}{r}100 \\
08\end{array}$ & none & & 40 & 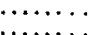 & 6 & $\begin{array}{l}6 \\
6\end{array}$ & (n....... \\
\hline $\begin{array}{l}\text { No. } 43 . \\
\text { No. } 44 .\end{array}$ & $\begin{array}{l}200 \\
200\end{array}$ & $\begin{array}{r}2 \\
12\end{array}$ & 98 & $\begin{array}{l}\text { none } \\
\text { none }\end{array}$ & $\begin{array}{l}40 \\
40\end{array}$ & 40 & $\cdots$ & 5 & 5 & [............. \\
\hline \multirow[t]{2}{*}{ No. 45} & 400 & 25 & 50 & 25 & 40 & 40 & 40 & 3 & 3 & 3 \\
\hline & 1,925 & 188 & & & & & & & & \\
\hline \multicolumn{11}{|l|}{$\begin{array}{l}\text { LaFollette Field-Campbell } \\
\text { Co., Tenn. }\end{array}$} \\
\hline No. ${ }^{4} 6 \ldots \ldots \ldots \ldots \ldots \ldots$ & 600 & 25 & 50 & 25 & 40 & 40 & 40 & 2 & 2 & 2 \\
\hline \multicolumn{11}{|l|}{$\begin{array}{l}\text { Coal Creek Field (b)-An- } \\
\text { derson and Campbell Co.. } \\
\text { Tenn. }\end{array}$} \\
\hline $\begin{array}{l}\text { No. } 47 \ldots \ldots \ldots \ldots \ldots \ldots \ldots \\
\text { No. }{ }_{48}^{8} \ldots \ldots \ldots \ldots \ldots \ldots \ldots\end{array}$ & $\begin{array}{l}400 \\
275\end{array}$ & none 15 & $\begin{array}{r}84 \\
100\end{array}$ & $\begin{array}{r}\mathbf{I} \\
\text { none }\end{array}$ & 40 & $\begin{array}{l}45 \\
50\end{array}$ & 45 & 4 & 4 & 4 \\
\hline No. $49 \ldots \ldots \ldots \ldots \ldots \ldots$ & 150 & & 95 & none & 45 & 45 & $\cdots$ & 4 & 4 & …......... \\
\hline \multirow{3}{*}{ No. $51 \ldots \ldots \ldots \ldots \ldots \ldots \ldots$} & 230 & $1^{2}$ & 88 & none & 40 & 45 & & 4 & 4 & $\ldots \ldots$ \\
\hline & $14^{\circ}$ & none & 100 & none & & 45 & $\cdots$ & & 42 & ... \\
\hline & $\mathrm{I}, 795$ & $\begin{array}{r}244 \\
13 \%\end{array}$ & & & & & & & & \\
\hline Grand Totals. & 27,905 & $\begin{array}{r}6,885 \\
24 \%\end{array}$ & & & & & & & & \\
\hline
\end{tabular}

(a) Fstimate of operators as to proportion of total wages consumed.

(b) All intoxicating drinks debarred from the Coal Field, No. 47.

(c) Small property owners draw the largest percentage of wages in cash. 
TABLE II.Continued.

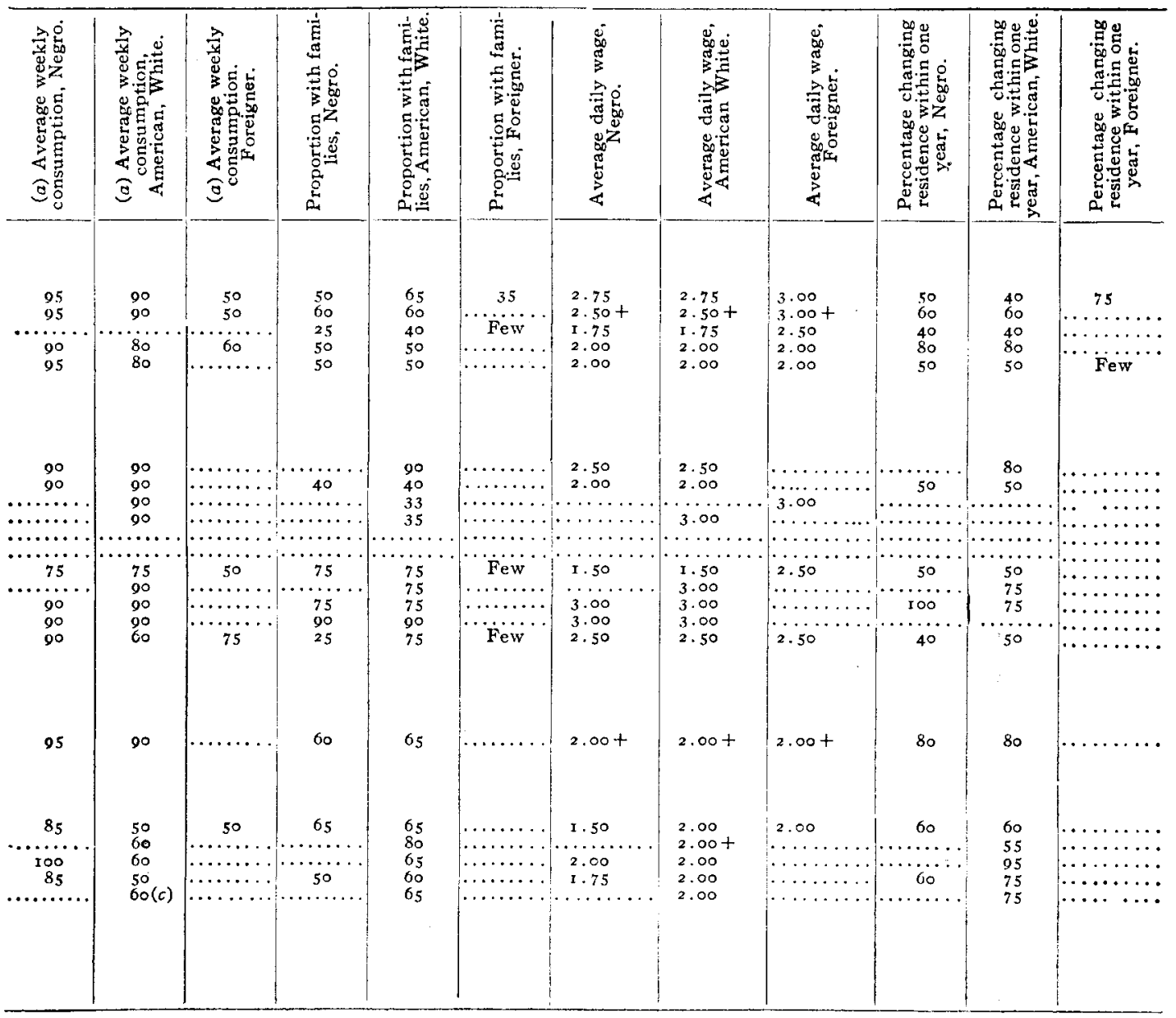


foreign laborers prefer isolation, and constitute more or less distinct colonies.

The presence of alcoholic drinks in the coal field is the greatest curse to the negro laborers. They are periodic drinkers, and having small regard for the saving of money, spend much of the wage for drink, which not only incapacitates them for labor, but leads them into serious vice and crime. Picnics, festivals, excursions, and baseball games offer the opportunity for heavy drinking, and these become periods of general carousals.

\section{B. Accessory Factors Infuencing Efficiency}

r. Field of Supply.-Most of the negro miners of this field come from Eastern Virginia, Southern Virginia, Southwest Virginia, East Tennessee and North Carolina. An examination into the recent migration of the negro population from these sections indicates that within the past decade, a very large number of those migrating have moved to cities and small towns, and that within recent years there has been a reaction against a general influx into the coal fields. The proportion of negro laborers employed in a number of the large operations has decreased since 1900 .

2. Classes Attracted.-It is difficult to differentiate the classes with precision, but at least three classes can always be recognized. The most important from the employer's standpoint is always the minority. This is what we may call the stable, conservative and efficient class. The majority of this class have either lived in the field for many years, or labor in the field regularly during a part of each year. As a rule they are of quiet, economical habits; and many of them "keep shack," and do their own cooking. A surprisingly large number of this class have purchased property near the place of their nativity.

There is another small class which is stable in residence and regular in work, but spend all on themselves, their homes and their friends. They maintain the highest standard of living, and are in reality the colored aristocracy of the coal field.

The great majority consists of those who are irregular in labor and unstable in residence. These are usually irregular in conduct, and the most flagrant abusers of property. About the only thing which can be said in their favor, from the employer's standpoint, is that they consume their wages as rapidly as earned. The employ- 
ers are, however, beginning to realize that the most costly labor is performed by this class, which is low in efficiency, and always approaching the limit of forbearance both as to credit and conduct.

3. Wages.-The wages paid must be considered high, as compared with the wage schedule of other countries, or with the wages paid in other lines of work in this country. By working nine hours per day, the average miner could easily make $\$ 2.00$ per day, and the exceptional miner $\$ 3.50$ to $\$ 4.00$ per day. The high wages do not create the greatest efficiency among the negro mining laborers, since so large a percentage of them are extravagant, with tendencies to irregularity and prodigality. The efficiency of this class would be increased by a lower scale of wages. The opposite is true when we turn to the economic, conservative class, since the higher the wage the greater the incentive and the opportunity to accumulate. High wages in reality invite irregularity, since by working half time the negro can make sufficient to satisfy partially his spending wants during the other half.

4. Absence of Investment Opportunity.-Many who denegerate both economically and morally could be saved from such a fate were there more investing opportunities in the field. The operators own almost all of the property in the vicinity of the mines, so that the negro who invests must save his money while in the field and invest it elsewhere. The temptation is too much for him. If he could purchase a small property and pay for it in small payments, he would save both his money and himself.

5. Strikes.-Nothing is more destructive to the organization and efficiency of this class of labor than strikes. One of the largest operators in West Virginia informed me that, prior to the strike of 1902, 50 per cent of his laborers were negroes; whereas, in 1907 they formed only to per cent. Negroes are entirely too suspicious of each other to become organized as a class, and are too unstable in their intentions to weather any kind of a protracted storm.

6. Homes.-Comfortable and sanitary houses in which to live react upon the laborers of any class, and if these are uncomfortable and unsanitary, the efficiency of the labor will be lowered, however regular be habits and conduct. In most parts of the field under discussion the houses are comfortable, but in many cases they are unsanitary. The conditions are naturally worst in those houses which are occupied by the most transient laborers, since the 
owners feel that they cannot afford to spend so much on properties from which they receive so little.

7. Saloons.-The general presence of saloons or accessibility to them throughout the West Virginia-Virginia-Kentucky part of the field is a very serious barrier to high efficiency. It reacts against the most healthful economic conditions. It is directly the cause of nine-tenths of the crimes committed, and is the cause of much of the vice prevailing. A number of careful and conservative observers in the field gave it as their opinion that 25 per cent of the total wages of the negroes is spent for drink. The resulting reputation from the serious crimes committed makes the territory unattractive to many hard-working, capable individuals, who would raise the standard of average merit and efficiency by their presence and labor.

8. Regulation.-The efficiency, not only of the negro laborers but of all classes of laborers, could be very materially raised by the employers instituting more severe regulations within their own operations. Very few of the operators (two or three) penalize their laborers for crime and disorder. Were this done, there would result a distinctly higher standard of community life, and a more capable aggregation of miners. It is a natural and advisable way of weeding out those who by their conduct and gross irregularity prove themselves a nuisance to the mine owner and the mining community.

9. Protection.-The police protection of the mining districts is a very important factor in the general regulation of and realizations from mining properties. A feeling of unsafety or uncertainty has its demoralizing effect both upon the workmen and their families. The absence of such protection gives the moral degenerate a freedom, which not only decreases his own efficiency, but reacts upon all about him. Since mining property is taxed according to its productive value, it becomes the duty of the state to see to it, that those who are demanded for the operation of these properties, should have adequate protection by law. The operators should co-operate with the state to meet this necessity, and the greatest efficiency can never be realized, either from the negro miners or any of the other classes involved, until there is adequate administration for regulating the physical condition and the conduct of each member of the community. 


\section{The Adjustment in Progress, and Prospective}

I. Relative Decrease in Number Employed.-The statistics of the past decade, and the present economic conditions indicate that the demand for regular and efficient laborers is becoming more urgent each year. The relative percentage of negro mining laborers employed now is much less than it was ten years ago. The figures are not available for determining the relative decrease, but four of the largest operators, employing a total of more than 12,000 laborers, estimate that the proportion of their negro laborers has decreased more than fifty per cent since 1900 . It is doubtful whether the present aggregation of negro miners is more efficient than it was in 1900, but the regular and high producers are esteemed by their employers in a way in which they were not during that earlier period.

The rapid development of the field and the improvements which have been made, both in equipment and organization, all combine to make the units of the organization of greater importance. Indeed, if intensity of language is any index, the mining operators have never thought so little of the irregular, irresponsible, unproductive miner.

Another element is entering to accentuate this prejudice, namely, the rapid influx of foreign laborers, the majority of whom are very productive laborers so long as they can be satisfied. The organization of foreign labor is always more difficult in the establishing stage of any line of work, and we therefore can expect that with the continued development of the various operations, the foreign labor will become more stable, efficient and satisfactory.

In the face of this situation, we believe that nothing can prevent a differentiation of the negro labor, which will result in strengthening the position of the better class of negro laborers, and in weeding out by selection the more inefficient.

2. Machine Mining as a Competitive Factor.-Machine mining becomes profitable only in large operations, where the conditions are favorable for the use of machinery. Within recent years the increase in the output of machine mined coal has been rapid, and there is no reason for believing that this rate of increase will be retarded, since consolidation throughout the area under discussion is in progress, and with the consolidation comes not only a more economic organization, but adequate capital for the development of 
properties on the most economic basis. We have already noted that the negro has yet to prove his ability to compete with American whites in the operation of mining machinery.

3. Checks to Migration.-In all parts of the field investigated, where railroad construction, the growth of towns, and the mining of iron are in progress, the negro laborers show their preference for work of this character. We believe that the present industrial situation in the states, (which supply the negro labor to this coal field,) points to a rapid increase in the demand for laborers in the home territory. The resources of Virginia, Tennessee, North and South Carolina are very great, and the demand for laborers in the fields of general construction and mining will be much increased in the near future. The growth of urban life in these states will also attract a large number of the negroes, many of whom would otherwise migrate to the coal field. Therefore the relative percentage of the negro laborers employed in this coal field will be decreased from without, as well as from within. 